\title{
Field Infection of Virus-Free Sugarcane by Sugarcane Yellow Leaf Virus and Effect of Yellow Leaf on Sugarcane Grown on Organic and on Mineral Soils in Florida
}

\author{
Wardatou Boukari, ${ }^{1}$ Claudia Kaye, ${ }^{2}$ Chunyan Wei, ${ }^{1,3}$ Martha Hincapie, ${ }^{1}$ Chris LaBorde, ${ }^{2}$ Michael Irey, ${ }^{2}$ and Philippe Rott $^{1, \dagger}$ \\ ${ }^{1}$ Plant Pathology Department, Everglades Research and Education Center, University of Florida, Belle Glade 33430, FL, U.S.A. \\ ${ }^{2}$ U.S. Sugar Corporation, Clewiston 33440, FL, U.S.A. \\ ${ }^{3}$ State Key Laboratory for Conservation and Utilization of Subtropical Agro-Bioresources, College of Agriculture, Guangxi Uni- \\ versity, Nanning 530005, China
}

\begin{abstract}
Sugarcane yellow leaf virus (SCYLV), the causal agent of yellow leaf, is widespread in Florida. Two field trials were set up, one on organic soil and one on mineral soil, to investigate the rate and timing of sugarcane infection by SCYLV under field conditions and the effect of the virus on yield. Each trial consisted of plots planted with healthy or SCYLV-infected seed cane of two commercial cultivars. Virus prevalence varied from 83 to $100 \%$ in plots planted with infected seed cane regardless of cultivar, location, and crop season. On organic soil,

highest SCYLV prevalence rates were 33 and $7 \%$ on organic and mineral soils, respectively. No significant negative effect of SCYLV on yield was found in plant cane crop regardless of cultivar and soil type. However, yield reductions in ratoon crops varied from nonsignificant to $27 \%$ depending on cultivar and soil type. Low virus prevalence observed after three crop seasons suggested that planting virus-free seed cane should limit the impact of SCYLV on sugarcane production in Florida.
\end{abstract} plants of virus-free plots became progressively infected in plant cane and first ratoon crops. On mineral soil, healthy sugarcane became initially infected in the first ratoon crop. After three crop seasons, the
Keywords: disease development and spread, epidemiology, tropical plants, viruses and viroids, yield loss and economic impacts
First described in Hawaii in 1989, yellow leaf (previously called yellow leaf syndrome) has been found in most sugarcane-growing areas around the world, including Florida (Rott et al. 2008). Symptoms of this disease include intense yellowing of the lower side of the sugarcane leaf midrib and necrosis proceeding from the tip toward the base of the leaf. The causal agent of yellow leaf is a Polerovirus called sugarcane yellow leaf virus (SCYLV). Based on entire genome sequences and the position of virus isolates in phylogenetic trees, occurrence of 11 genotypes of the virus has been reported: BRA, CHN1, CHN3, CUB, FLA1, FLA2, FLA3, HAW, IND, PER, and REU (Abu Ahmad et al. 2006a; Chinnaraja et al. 2013; Filloux et al. 2018; Lin et al. 2014; Wang et al. 2012). Based on sequence alignment and pairwise identity calculation methods, it was suggested to recognize only seven genotypes (BRA, CHN1, CUB, FLA1, FLA2, FLA3, and REU) that were also distributed in two major phylogenetic clades (Filloux et al. 2018). The biological significance of this genetic diversity is unknown, but genotype CUB was more virulent than genotype BRA in controlled inoculation studies (Abu Ahmad et al. 2007).

Yellow leaf can cause significant yield losses, with the most notable case in Brazil in the 1990s that resulted in a 25\% crop loss (Rott et al. 2008; Vega et al. 1997). Over the years, the effect of SCYLV on sugarcane yields has been investigated in numerous geographical locations around the world: in Reunion Island (Rassaby et al. 2003), India (Viswanathan et al. 2014), Hawaii (Lehrer et al. 2009; Zhu et al. 2010), Louisiana (Grisham et al. 2002, 2009), and Florida

${ }^{\dagger}$ Corresponding author: P. Rott; pcrott@ufl.edu

Funding: This research was funded by the Florida Sugar Cane League (project 00107475 and fund F000057). This work was also supported by the U.S. Department of Agriculture National Institute of Food and Agriculture (project Hatch/Rott FLA-BGL-005404).

The author(s) declare no conflict of interest.

Accepted for publication 8 April 2019.

(C) 2019 The American Phytopathological Society
(Comstock and Miller 2004). This was often done by comparing a range of growth (stalk height and diameter, etc.) and yield (stalk weight, juice quality, etc.) parameters between healthy, tolerant, or resistant sugarcane and SCYLV-infected sugarcane. In Florida, the only study investigating the impact of SCYLV infection on sugarcane yields was undertaken $>10$ years ago, and it revealed an overall $11 \%$ yield reduction using sugarcane cultivars grown in the 2000s (Comstock and Miller 2004). However, the effect of SCYLV on cultivars currently grown in the Everglades Agricultural Area is unknown.

SCYLV is not transmitted mechanically, but it is spread by infected stalk cuttings and at least four aphid species. These aphids include Ceratovacuna lanigera, Melanaphis sacchari, Rhopalosiphum maidis, and Rhopalosiphum rufiabdominalis (Rott et al. 2008; Schenck and Lehrer 2000). Among these aphids, the most efficient and widespread vector in the Western Hemisphere is M. sacchari, commonly known as the sugarcane aphid. Most sugarcane varieties infected by SCYLV have no visible symptoms, and cuttings taken from infected plants can, therefore, easily spread the disease. Because sugarcane is a vegetatively propagated crop and partly because of pervasiveness of the SCYLV vector(s), yellow leaf has been controlled by replacing susceptible cultivars with resistant or tolerant ones and/or planting virus-free seed cane from tissue culture. Nevertheless, sources of resistance to SCYLV are quite limited in both the ancestral sugarcane species (Saccharum officinarum, Saccharum spontaneum, etc.) and commercial sugarcane cultivars, which are Saccharum interspecific hybrids (Comstock et al. 1998, 2001; Filloux et al. 2018).

Because most sugarcane varieties grown in the 1990s were infected by SCYLV, disease-free nurseries planted with virus-free seed cane were deployed in Florida since 2000 to reduce incidence of SCYLV (Rott et al. 2016). However, a metagenomics study looking at the sugarcane virome in Florida revealed that prevalence of SCYLV in 2013 to 2014 was $>70 \%$ in commercial fields and germplasm collections (Filloux et al. 2018). Such high prevalence of the virus in local germplasm collections supported the previous studies that revealed limited resistance to SCYLV in S. officinarum and S. spontaneum (Comstock et al. 1998, 2001). The high prevalence of SCYLV in commercial fields also suggested that the deployment 
of aforementioned sugarcane nurseries was only partially effective in reducing incidence of the virus in commercial fields in Florida.

Rapidity of infection of healthy planting material plays a key role in successful control of yellow leaf. Depending on the location and the distance between healthy and infected plants, SCYLV incidence varied from 3 to $95 \%$ in 1- to 12-month-old sugarcane planted with virus-free seed cane in Gualeloupe (Daugrois et al. 2011; Edon-Jock et al. 2009), Hawaii (Komor et al. 2010; Lehrer et al. 2007), Louisiana (McAllister et al. 2008), and Reunion (Rassaby et al. 2004). In Florida, the rate of SCYLV infection in the field was found to be cultivar dependent and ranged from 28 to

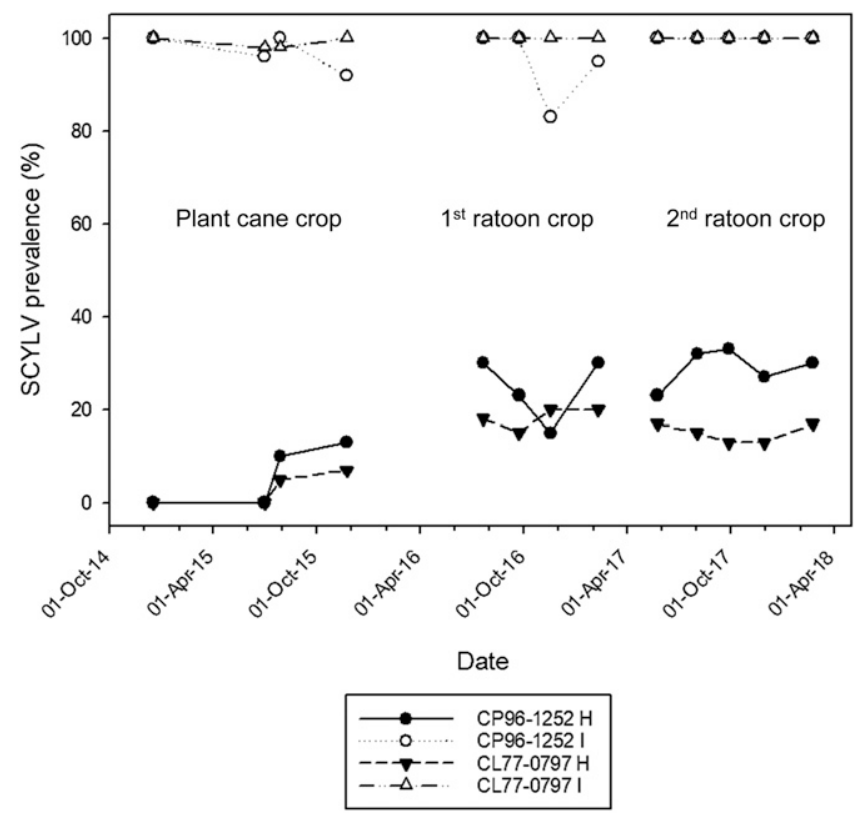

Fig. 1. Progress of prevalence of sugarcane yellow leaf virus (SCYLV) in two sugarcane cultivars grown on organic soil (at Ritta) during three crop seasons. Each data point represents the percentage of infection for a total of 60 leaves (10 leaves per plot).

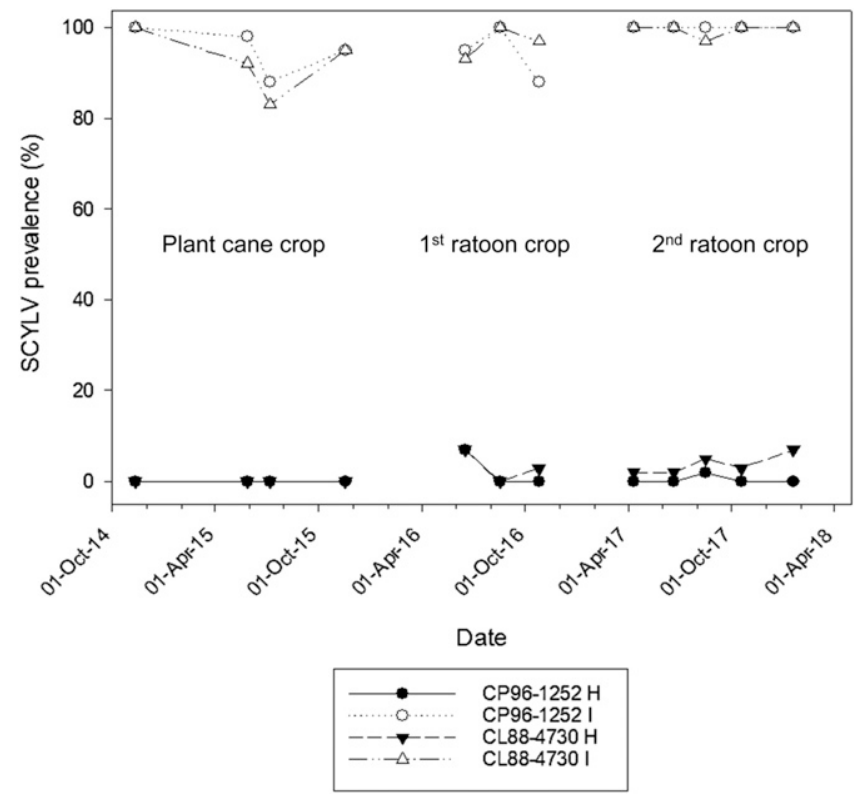

Fig. 2. Progress of prevalence of sugarcane yellow leaf virus (SCYLV) in two sugarcane cultivars grown on mineral soil (at Townsite) during three crop seasons. Each data point represents the percentage of infection for a total of 60 leaves (10 leaves per plot).
$86 \%$ in 2004 by the end of a 2-year experiment comparing tissue culture (virus free) and hot water-treated bud-propagated (SCYLVinfected) seed cane of five sugarcane cultivars (Comstock and Miller 2004). In the 2010s, several commercial sugarcane fields were found entirely infected with SCYLV.

Therefore, the objectives of this study were to (1) determine the rapidity and frequency of SCYLV infection of virus-free sugarcane under Florida's field conditions in 2015 to 2017, (2) identify the virus genotypes that are currently spread in the field, and (3) determine the effect of SCYLV on sugarcane yields of cultivars currently grown in Florida.

\section{Materials and Methods}

Experimental fields. Sugarcane plants from seed cane fields in Clewiston, Florida were tested by tissue blot immunoassay (TBIA) using the top visible dewlap leaf as described by Schenck et al. (1997) and modified by Girard et al. (2010). Virus-free and virusinfected stalks were used to set up two sugarcane trials surrounded by commercial fields in Clewiston (U.S. Sugar Corporation). One trial was established on mineral (sand) soil at the Townsite location on 11 November 2014 with cultivars CP96-1252 and CL88-4730. This mineral soil is known as Margate sand soil (siliceous; hyperthermic Mollic Psammaquent) (USDA-NRCS 1991). The other trial was planted on organic (muck) soil on 17 December 2014 at the Ritta location using cultivars CP96-1252 and CL77-0797. This organic soil is known as Terra Ceia muck soil (euic; hyperthermic Typic Medisaprists). A randomized block design with six replications was used for each trial. Each plot consisted of six rows of $13.1 \mathrm{~m}$ each and was planted with virus-free or virus-infected seed cane of each cultivar. Within each block, plots were separated by $4.6 \mathrm{~m}$, and consecutive blocks were planted $6.1 \mathrm{~m}$ apart. Each experimental field was $217-\mathrm{m}$ long and 44.2-m wide.

Prevalence of SCYLV in sugarcane cultivars. The top visible dewlap leaf was randomly collected from 10 stalks in each plot on three, four, and five different sampling dates in plant cane, first ratoon, and second ratoon crop, respectively. Presence of SCYLV in each leaf was determined by TBIA as described above. Prevalence of SCYLV in each cultivar and healthy/infected plants was expressed as the percentage of infection of 60 leaves (10 leaves from each of the six replicates in each trial).

Determination of SCYLV genotypes in virus-infected leaves. Identity of SCYLV genotypes was determined during the first ratoon crop and before the harvest of the second ratoon crop. At each sampling date, total RNA was extracted from 24 randomly selected TBIA-positive sugarcane leaves from each trial with the Qiagen RNeasy Plant Mini Kit (Qiagen) following the manufacturer's protocol. RNA was suspended in $30 \mu \mathrm{l}$ of RNAse-free water and stored at $-20^{\circ} \mathrm{C}$ until further use. To confirm the presence of SCYLV and quality of RNA extraction, samples were first subjected to a onestep reverse transcription PCR (RT-PCR) using Qiagen's OneStep RT-PCR Kit and primers ScYLVf1 and ScYLVr1 as described by Girard et al. (2010), except that agarose gels were stained with Sybr green before visualization under ultraviolet light. RNA samples showing a positive reaction (219-bp amplicon) were then subjected to RT-PCR with the Qiagen's OneStep RT-PCR Kit using genotypespecific primers sets BRA-PER-F/BRA-PER-R and CUB-F/CUB-R as described by Abu Ahmad et al. (2006b). The expected sizes of the amplicon for genotype BRA-PER and genotype CUB were 362 and $450 \mathrm{bp}$, respectively.

Of the 24 RT-PCR-positive samples with genotype-specific primers from each trial, four at Townsite (mineral soil) and five at Ritta (organic soil) were randomly selected in first ratoon crop, whereas four from Townsite and eight from Ritta were randomly selected in second ratoon crop. PCR products were purified using the Qiagen PCR purification kit following the manufacturer's protocol. Purified PCR products were sequenced using the Sanger method by Eton Bioscience Inc. The resulting sequences were cleaned with Geneious version R11.1.5 software (Biomatters) and then compared by BLASTn with SCYLV genotype sequences in the GenBank database (Filloux et al. 2018). 
Determination of yields. The number of growing stalks in each plot was estimated in first and second ratoon crops by counting the number of tillers of two inner rows. Counting was performed 6 and 7 months postharvest in first ratoon crop for Ritta and Townsite, respectively, and 7 and 8 months after harvest in second ratoon crop for Ritta and Townsite, respectively.

Sugarcane stalk weight was determined using two different sampling procedures. The 10 -stalk method consisted of randomly collecting, cutting by hand, and weighing 10 stalks from each plot when cane was 12 months old in each crop cycle. The two-row method consisted of harvesting all stalks from two inner rows of each plot with a Cameco sugarcane harvester and weighing the stalks with a hydraulic scale (U.S. Sugar). This latter method was applied when cane was 15 months old in plant cane and 12 months old in first and second ratoon crops, with the exception of first ratoon crop at Townsite (mineral soil).

Sucrose content was determined in the stalks collected by the 10stalk method in each crop cycle. After being weighed, stalks were crushed using a rolling mill. The resulting juice was analyzed for sucrose concentration at the U.S. Sugar Corporation Laboratory by near-infrared spectroscopy using an FOSS NIR System 5000 liquid analyzer. Cane tonnage per hectare was inferred using total stalk weight measured by the two-row method. Sugar tonnage per hectare was inferred using both cane tonnage per hectare and sucrose content measured by the 10 -stalk method.

Statistical analysis of data. The statistical program $\mathrm{R}$ version 3.2.3 (Hothorn et al. 2017; Lenth et al. 2018) (R Core Team) was used for statistical analyses. The yield data (10-stalk weight, sucrose content and amount, two-row stalk number, and cane and sugar tonnage) were analyzed for each year and location using a linear mixed model. For each parameter, means between cultivars, treatments (infected versus noninfected plants), location (Ritta versus Townsite), and crop season (plant cane and first and second ratoon crops) were

Table 1. Prevalence of sugarcane yellow leaf virus (SCYLV) in sugarcane plots planted with healthy seed cane and grown for three crop seasons at Ritta (organic soil) and Townsite (mineral soil)

\begin{tabular}{lcc}
\hline Crop season & Cultivar & $\begin{array}{c}\text { Highest SCVLV } \\
\text { prevalence (\%) }\end{array}$ \\
\hline Ritta (organic soil) & & \\
Plant cane (2014-2016) & CP96-1252 & 13 \\
Plant cane (2014-2016) & CL77-0797 & 7 \\
First ratoon (2016-2017) & CP96-1252 & 30 \\
First ratoon (2016-2017) & CL77-0797 & 20 \\
Second ratoon (2017-2018) & CP96-1252 & 33 \\
Second ratoon (2017-2018) & CL77-0797 & 17 \\
Linear mixed effect & & $F<P$ \\
Cultivar effect & & $<0.0001$ \\
Sampling effect (within crop season) & & 0.004 \\
Crop season effect & & $<0.0001$ \\
Cultivar $\times$ sampling effect & & 0.642 \\
Cultivar $\times$ crop season effect & & 0.340 \\
Sampling effect (between crop season) & & 0.005 \\
Townsite (mineral soil) & & \\
Plant cane (2014-2016) & CP96-1252 & 0 \\
Plant cane (2014-2016) & CL88-4730 & 0 \\
First ratoon (2016-2017) & CP96-1252 & 7 \\
First ratoon (2016-2017) & CL88-4730 & 7 \\
Second ratoon (2017-2018) & CP96-1252 & 2 \\
Second ratoon (2017-2018) & CL88-4730 & 7 \\
Linear mixed effect & & $F<P$ \\
Cultivar effect & & $<0.0001$ \\
Sampling effect (within crop season) & & 0.490 \\
Crop season effect & & 0.004 \\
Cultivar $\times$ sampling effect & & 0.015 \\
Cultivar $\times$ crop season effect & & 0.526 \\
Sampling effect (between crop season) & & 0.168 \\
\hline St & & \\
\hline
\end{tabular}

${ }^{\mathrm{z}}$ Statistical analyses were performed with all prevalence data (Figs. 1 and 2). compared by the Tukey method using the multicomp package in program R. Virus prevalence data were analyzed using a logistic regression with negative binomial errors. For each trial, replications were considered as a random variable, and treatments were considered as a fixed variable. Lme4 and Emmeans package were used for linear mixed model and logistic regression, respectively.

\section{Results}

Field infection. Virus prevalence varied from 83 to $100 \%$ in plots planted with infected seed cane regardless of cultivar, location, and crop season (Figs. 1 and 2). SCYLV was not detected in virus-free plots at first sampling date, but plants in these plots became progressively infected on organic soil in plant cane (Fig. 1). At the end of this crop, prevalence rates of SCYLV in CL77-0797 and CP96-1252 at Ritta were 7 and $13 \%$, respectively. Prevalence rates of the virus in these two cultivars increased in first ratoon crop with maximum values of $20 \%$ in CL77-0797 and 30\% in CP96-1252. Similar values were observed in second ratoon crop, where highest prevalence was 17\% in CL77-0797 and 33\% in CP96-1252.

Over the course of the three crop seasons at Ritta, plots of CP961252 planted with healthy seed cane were more infected by SCYLV than the same plots of CL77-0797 $(P<0.0001$ for cultivar effect) (Table 1). Sampling effect within crop season, crop season effect, and sampling effect between crop season were significant $(P=$ $0.004, P<0.0001$, and $P=0.005$, respectively), but there was no cultivar $\times$ sampling effect and no cultivar $\times$ crop season effect (Table 1).

Table 2. Genotypes of sugarcane yellow leaf virus (SCYLV) identified in two sugarcane cultivars grown at Ritta on organic soil

\begin{tabular}{|c|c|c|c|c|c|}
\hline \multirow[b]{2}{*}{$\begin{array}{l}\text { Crop season } \\
\text { and cultivar }\end{array}$} & \multirow{2}{*}{$\begin{array}{l}\text { Infection } \\
\text { status at } \\
\text { planting }^{\mathrm{z}}\end{array}$} & \multirow{2}{*}{$\begin{array}{l}\text { Number } \\
\text { of leaf } \\
\text { samples }\end{array}$} & \multicolumn{3}{|c|}{$\begin{array}{l}\text { Number of samples infected } \\
\text { with SCYLV genotype }\end{array}$} \\
\hline & & & BRA & CUB & $\begin{array}{l}\text { BRA + } \\
\text { CUB }\end{array}$ \\
\hline \multicolumn{6}{|l|}{$\begin{array}{l}\text { First ratoon } \\
(2016-2017)\end{array}$} \\
\hline СР96-1252 & + & 6 & 6 & 0 & 0 \\
\hline СР96-1252 & - & 6 & 6 & 0 & 0 \\
\hline CL77-0797 & + & 6 & 5 & 0 & 1 \\
\hline CL77-0797 & - & 6 & 4 & 2 & 0 \\
\hline \multicolumn{6}{|l|}{$\begin{array}{r}\text { Second ratoon } \\
(2017-2018)\end{array}$} \\
\hline СР96-1252 & + & 6 & 6 & 0 & 0 \\
\hline CP96-1252 & - & 7 & 4 & 0 & 3 \\
\hline CL77-0797 & + & 6 & 3 & 0 & 3 \\
\hline CL77-0797 & - & 5 & 2 & 2 & 1 \\
\hline
\end{tabular}

${ }^{\mathrm{z}}+$, infected by SCYLV; - , noninfected by SCYLV.

Table 3. Genotypes of sugarcane yellow leaf virus (SCYLV) identified in two sugarcane cultivars grown at Townsite on mineral soil

\begin{tabular}{cccccc}
\hline & & & \multicolumn{3}{c}{$\begin{array}{c}\text { Number of samples infected } \\
\text { with SCYLV genotype }\end{array}$} \\
\cline { 5 - 7 } $\begin{array}{c}\text { Crop season } \\
\text { and cultivar }\end{array}$ & $\begin{array}{c}\text { Infection } \\
\text { status at } \\
\text { planting }\end{array}$ & $\begin{array}{c}\text { Number } \\
\text { of leaf } \\
\text { samples }\end{array}$ & BRA & CUB & $\begin{array}{c}\text { BRA + } \\
\text { CUB }\end{array}$ \\
\hline First ratoon & & & & & \\
$(2016-2017)$ & & & & & \\
CP96-1252 & + & 12 & 12 & 0 & 0 \\
CP96-1252 & - & 0 & 0 & 0 & 0 \\
CL88-4730 & + & 11 & 11 & 0 & 0 \\
CL88-4730 & - & 1 & 1 & 0 & 0 \\
Second ratoon & & & & & \\
(2017-2018) & & & & & \\
CP96-1252 & + & 10 & 10 & 0 & 0 \\
CP96-1252 & - & 0 & 0 & 0 & 0 \\
CL88-4730 & + & 11 & 11 & 0 & 0 \\
CL88-4730 & - & 3 & 3 & 0 & 0 \\
\hline
\end{tabular}

${ }^{\mathrm{z}}+$, infected by SCYLV; - , noninfected by SCYLV. 
SCYLV was not detected in virus-free plots on mineral soil at any of the four sampling dates in plant cane, and sugarcane became infected only in the first ratoon crop (Fig. 2). After 4 months of growth in the first ratoon crop at Townsite, prevalence of the virus was 7\% in both cultivars (CP96-1252 and CL88-4730). The virus was not detected by TBIA after 6 and 8 months of growth of CP96-1252, and prevalence of SCYLV was only 3\% in CL88-4730 at the end of the first ratoon crop when sugarcane was 12 months old (Fig. 2). Similar values were observed in the second ratoon crop when highest prevalence rates were 2 and 7\% in CP96-1252 and CL88-4730, respectively.

Over the course of the three crop seasons at Townsite, plots of CL88-4730 planted with healthy seed cane were slightly more infected by SCYLV than the same plots of CP96-1252 $(P<0.0001$ for cultivar effect) (Table 1). Crop season effect and cultivar $\times$ sampling effect were significant $(P=0.004$ and $P=0.015$, respectively), but there was no sampling effect within the crop season, no cultivar $\times$ crop season effect, and no sampling $\times$ crop season effect (Table 1).

None of the plants at Ritta or Townsite showed yellowing of the midrib or leaf necrosis starting from the tip, regardless of the crop cycle.

SCYLV genotypes. SCYLV was detected by RT-PCR in all samples that tested positive by TBIA. At Ritta (organic soil), genotypes BRA and CUB were found in first ratoon crop in 22 and 3 of 24 samples, respectively, including one mixed infection with both genotypes (Table 2). In second ratoon crop, genotype BRA was present in 22 of 24 samples, and genotype CUB was in 9 samples, including seven mixed infections. Mixed infections were found in plots planted with infected seed cane (CL77-0797) and plots that were initially virus free (CP96-1252 and CL77-0797). At Townsite (mineral soil), SCYLV genotype BRA was found in all 48 samples collected in first and second ratoon crops (Table 3). No sample collected at this location was found infected by genotype CUB.

The partial coat protein sequences of genotype BRA obtained in our study showed $99 \%$ identity among each other and 98 to $99 \%$ sequence identity with SCYLV isolate CHN-GD-ZJ4 (GenBank accession number HQ245319.1) and isolate CHN-HN (GenBank accession number HQ342888.1), both members of the BRA clade. Genotype CUB sequences had 99\% identity among each other and 98\% with SCYLV isolate chn1 (GenBank accession number GU327735.1), a member of the CUB clade.

Effect of yellow leaf on sugarcane yields. At Ritta (organic soil), with the exception of the 10-stalk sucrose content, no significant effect of SCYLV infection was found on yield at harvest of the plant cane crop regardless of cultivar and harvest method (Table 4). In plant cane, $100 \%$ infected stalks of both cultivars (CP96-1252 and CL77-0797) contained overall more sucrose than noninfected (CL77-0797) or low-infected stalks (CP96-1252; $P=0.0386$ ) (Table 4). At the end of first ratoon crop at Ritta, a significant negative effect of virus infection was observed for four of six measured parameters: 10-stalk sucrose content, 10-stalk sucrose amount, two-row stalk number, and sugar tonnage per hectare. The infection effect on cane tonnage per hectare was close to $5 \%$ significance $(P=$ $0.0544)$. Sucrose amount of 10 stalks was $19 \%$ lower in $100 \%$

Table 4. Effect of sugarcane yellow leaf virus (SCYLV) on yield of two sugarcane cultivars grown on organic soil (Ritta) for three crop seasons

\begin{tabular}{|c|c|c|c|c|c|c|c|}
\hline $\begin{array}{l}\text { Crop cycle and } \\
\text { cultivar }\end{array}$ & $\begin{array}{c}\text { SCYLV } \\
\text { prevalence }^{\mathrm{x}}(\%)\end{array}$ & $\begin{array}{c}\text { 10-Stalk } \\
\text { weight }(\mathrm{kg})^{\mathrm{y}}\end{array}$ & $\begin{array}{l}\text { 10-Stalk sucrose } \\
\text { concentration }(\%)^{\mathrm{y}}\end{array}$ & $\begin{array}{c}\text { 10-Stalk sucrose } \\
\text { amount }^{\mathbf{y}}\end{array}$ & $\begin{array}{c}\text { Two-row stalk } \\
\text { number }^{\mathbf{y}}\end{array}$ & $\begin{array}{l}\text { Tons cane } \\
\text { per } 1 \text { ha }^{y, z}\end{array}$ & $\begin{array}{l}\text { Tons sugar } \\
\text { per } 1 \text { ha }^{\mathrm{y}, \mathrm{z}}\end{array}$ \\
\hline \multicolumn{8}{|l|}{$\begin{array}{l}\text { Plant cane } \\
(2014-2016)\end{array}$} \\
\hline СР96-1252 & 100 & $14.04 \mathrm{ab}$ & $17.90 \mathrm{ab}$ & $2.52 \mathrm{ab}$ & na & $136.74 \mathrm{a}$ & $24.48 \mathrm{a}$ \\
\hline СР96-1252 & 13 & $12.48 \mathrm{a}$ & $17.45 \mathrm{a}$ & $2.18 \mathrm{a}$ & na & $133.94 \mathrm{a}$ & $23.42 \mathrm{a}$ \\
\hline CL77-0797 & 100 & $15.32 \mathrm{~b}$ & $18.22 \mathrm{~b}$ & $2.79 \mathrm{~b}$ & na & $130.95 \mathrm{a}$ & $23.85 \mathrm{a}$ \\
\hline CL77-0797 & 0 & $15.99 \mathrm{~b}$ & $17.88 \mathrm{ab}$ & $2.86 \mathrm{~b}$ & na & $135.06 \mathrm{a}$ & $24.16 \mathrm{a}$ \\
\hline $\begin{array}{l}\text { Linear mixed } \\
\text { effect }\end{array}$ & & $F<P$ & & & & & \\
\hline Cultivar effect & & 0.0025 & 0.0481 & 0.0021 & na & 0.7408 & 0.9688 \\
\hline Infection effect & & 0.5076 & 0.0386 & 0.3347 & na & 0.9261 & 0.7819 \\
\hline $\begin{array}{l}\text { Cultivar } \times \\
\text { infection effect }\end{array}$ & & 0.1137 & 0.7566 & 0.139 & na & 0.6253 & 0.6179 \\
\hline \multicolumn{8}{|l|}{$\begin{array}{l}\text { First ratoon } \\
\quad(2016-2017)\end{array}$} \\
\hline СР96-1252 & 100 & $18.71 \mathrm{a}$ & $18.41 \mathrm{a}$ & $3.45 \mathrm{a}$ & $380 \mathrm{a}$ & $110.78 \mathrm{a}$ & $20.40 \mathrm{ab}$ \\
\hline СР96-1252 & 30 & $18.40 \mathrm{a}$ & $18.79 \mathrm{ab}$ & $3.46 \mathrm{a}$ & $420 \mathrm{a}$ & $112.83 \mathrm{a}$ & $21.16 \mathrm{a}$ \\
\hline CL77-0797 & 100 & $19.11 \mathrm{ab}$ & $18.70 \mathrm{ab}$ & $3.57 \mathrm{a}$ & $272 b$ & $97.07 \mathrm{~b}$ & $18.16 \mathrm{~b}$ \\
\hline CL77-0797 & 20 & $22.68 \mathrm{~b}$ & $19.39 \mathrm{~b}$ & $4.40 \mathrm{~b}$ & $308 \mathrm{~b}$ & $108.72 \mathrm{ab}$ & $21.08 \mathrm{a}$ \\
\hline $\begin{array}{l}\text { Linear mixed } \\
\text { effect }\end{array}$ & & $F<P$ & & & & & \\
\hline Cultivar effect & & 0.0237 & 0.0555 & 0.0088 & $<0.0001$ & 0.0161 & 0.0881 \\
\hline Infection effect & & 0.1000 & 0.0244 & 0.0330 & 0.0046 & 0.0544 & 0.0113 \\
\hline $\begin{array}{l}\text { Cultivar } \times \\
\text { infection effect }\end{array}$ & & 0.0544 & 0.4828 & 0.0355 & 0.8657 & 0.1645 & 0.1106 \\
\hline \multicolumn{8}{|l|}{$\begin{array}{l}\text { Second ratoon } \\
(2017-2018)\end{array}$} \\
\hline СР96-1252 & 100 & $19.66 \mathrm{a}$ & $18.70 \mathrm{ab}$ & $3.67 \mathrm{a}$ & 418 a & $96.02 \mathrm{a}$ & $17.96 \mathrm{a}$ \\
\hline СР96-1252 & 33 & $17.31 \mathrm{a}$ & $18.62 \mathrm{a}$ & $3.22 \mathrm{a}$ & $444 \mathrm{a}$ & $93.93 \mathrm{a}$ & $17.49 \mathrm{a}$ \\
\hline CL77-0797 & 100 & $16.70 \mathrm{a}$ & $19.09 \mathrm{ab}$ & $3.19 \mathrm{a}$ & $298 \mathrm{~b}$ & $76.59 \mathrm{a}$ & $14.62 \mathrm{a}$ \\
\hline CL77-0797 & 17 & $17.58 \mathrm{a}$ & $19.54 \mathrm{~b}$ & $3.43 \mathrm{a}$ & $313 \mathrm{~b}$ & $92.66 \mathrm{a}$ & $18.11 \mathrm{a}$ \\
\hline $\begin{array}{l}\text { Linear mixed } \\
\text { effect }\end{array}$ & & $F<P$ & & & & & \\
\hline Cultivar effect & & 0.1270 & 0.0077 & 0.4365 & $<0.0001$ & 0.1151 & 0.2640 \\
\hline Infection effect & & 0.3900 & 0.4009 & 0.5668 & 0.1260 & 0.2765 & 0.2172 \\
\hline $\begin{array}{l}\text { Cultivar } \times \\
\text { infection effect }\end{array}$ & & 0.0700 & 0.2385 & 0.0598 & 0.6670 & 0.1630 & 0.1124 \\
\hline
\end{tabular}

${ }^{x}$ Highest prevalence of SCYLV during the crop cycle.

${ }^{y}$ In the column and for each crop cycle, the data followed by the same letter are nonsignificantly different at $P=0.05$ according to Tukey's test; na, not available.

${ }^{\mathrm{z}}$ Tonnage calculated based on two-row weight data. 
virus-infected stalks of CL77-0797 than in 20\% virus-infected stalks of this cultivar. Sugar tonnage per hectare determined by harvesting two sugarcane rows was also significantly reduced by $14 \%$ in $100 \%$ virus-infected plots of CL77-0797. In second ratoon crop at Ritta, no significant infection effect was found after analysis of data combined for both cultivars (Table 4). However, when data were analyzed separately for each cultivar (data not shown), cane tonnage per hectare and sugar tonnage per hectare were significantly lower $(P \leq 0.05)$ in 100\% virus-infected stalks of CL77-0797 compared with 17\% infected stalks. In this cultivar, cane tonnage per hectare and sugar tonnage per hectare were significantly reduced by $17 \%$ (76.59 versus 92.66 ) and $19 \%$ (14.62 versus 18.11$)$, respectively.

At Townsite (mineral soil), no significant effect of SCYLV infection was found on yield at harvest of plant cane and first ratoon crops regardless of cultivar and harvest method (Table 5). In first ratoon crop, 10-stalk yield parameters and the two-row stalk number were different between CP96-1252 and CL88-4730 but not between $100 \%$ infected plots and low-infected plots $(7 \%)$ of each cultivar. In second ratoon crop, a significant negative effect of SCYLV infection was found for cane tonnage per hectare $(P=0.0031)$ and sugar tonnage per hectare $(P=0.0017)$. The tonnage of cane per hectare and the tonnage of sugar per hectare in $100 \%$ infected plots of CP96-1252 were $27 \%$ lower (50.66 versus 69.31 and 10.2 versus 13.93 , respectively) than in sugarcane plots that were almost not infected (2\%) (Table 5). No difference in yield parameters between these two groups of plants was detected based on 10-stalk sampling. Yield parameters of sugarcane CL88-4730 were not different between infected (100\%) and almost noninfected (7\%) plots regardless of harvest method.

\section{Discussion}

Despite the close proximity to SCYLV-infected plots serving as inoculum source for virus transmission, healthy plants of three sugarcane cultivars became infected at low levels after three crop seasons. At the end of second ratoon crop, maximum prevalence of SCYLV was $33 \%$ at Ritta and only $7 \%$ at Townsite. Differences in vector activity relevant to each location and soil type could explain the variation in virus prevalence between the two locations of a common sugarcane cultivar (CP96-1252). SCYLV is vectored by the sugarcane aphid $M$. sacchari, and invasion of plants by winged aphids depends on their capacity to land on their host through visual contrast of the soil background and the host plant green foliage (Kennedy et al. 1959, 1961; Kring 1972). Soil at Ritta was organic (black muck) soil, whereas soil at Townsite was mineral (gray sand) soil, and differences in soil color may have influenced sugarcane invasion capacity of aphids.

Populations of M. sacchari also vary during the year. According to Hall (1987), the highest populations of this aphid in Florida occurred between the months of June and July in 1985. However, based on our own observations during 2014 to 2018 , the sugarcane aphid is currently only found on sugarcane for a 6- to 8-week period from March to April. Furthermore, the sugarcane aphid is also hosted by Columbus grass (Sorghum almum), a weed that is very common around sugarcane fields and also infected by SCYLV in Florida

Table 5. Effect of sugarcane yellow leaf virus (SCYLV) on yield of two sugarcane cultivars grown on mineral soil (Townsite) for three crop seasons

\begin{tabular}{|c|c|c|c|c|c|c|c|}
\hline $\begin{array}{l}\text { Crop cycle and } \\
\text { cultivar }\end{array}$ & $\begin{array}{c}\text { SCYLV } \\
\text { prevalence }^{\mathrm{x}}(\%)\end{array}$ & $\begin{array}{c}\text { 10-Stalk } \\
\text { weight }(\mathbf{k g})^{\mathrm{y}}\end{array}$ & $\begin{array}{l}\text { 10-Stalk sucrose } \\
\text { concentration }(\%)^{\mathrm{y}}\end{array}$ & $\begin{array}{c}\text { 10-Stalk sucrose } \\
\text { amount }^{\mathbf{y}}\end{array}$ & $\begin{array}{c}\text { Two-row stalk } \\
\text { number }\end{array}$ & $\begin{array}{l}\text { Tons cane } \\
\text { per } 1 \mathrm{ha}^{\mathrm{y}, \mathrm{z}}\end{array}$ & $\begin{array}{l}\text { Tons sugar } \\
\text { per } 1 \mathrm{ha}^{\mathrm{y}, \mathrm{z}}\end{array}$ \\
\hline \multicolumn{8}{|l|}{$\begin{array}{l}\text { Plant cane } \\
(2014-2016)\end{array}$} \\
\hline СР96-1252 & 98 & $13.34 \mathrm{a}$ & $19.07 \mathrm{ab}$ & $2.54 \mathrm{a}$ & na & $140.30 \mathrm{ab}$ & $26.72 \mathrm{a}$ \\
\hline СР96-1252 & 0 & $12.91 \mathrm{a}$ & $18.41 \mathrm{a}$ & $2.38 \mathrm{a}$ & na & $148.70 \mathrm{a}$ & $27.33 \mathrm{a}$ \\
\hline CL88-4730 & 95 & $13.57 \mathrm{a}$ & $19.82 \mathrm{bc}$ & $2.69 \mathrm{a}$ & na & $123.67 \mathrm{ab}$ & $24.54 \mathrm{a}$ \\
\hline CL88-4730 & 0 & $11.75 \mathrm{a}$ & $20.55 \mathrm{c}$ & $2.42 \mathrm{a}$ & na & $121.80 \mathrm{~b}$ & $24.98 \mathrm{a}$ \\
\hline $\begin{array}{l}\text { Linear mixed } \\
\text { effect }\end{array}$ & & $F<P$ & & & & & \\
\hline Cultivar effect & & 0.5179 & 0.0001 & 0.5417 & na & 0.037 & 0.0707 \\
\hline Infection effect & & 0.1336 & 0.9053 & 0.1638 & na & 0.6137 & 0.6592 \\
\hline $\begin{array}{l}\text { Cultivar } \times \\
\text { infection effect }\end{array}$ & & 0.3391 & 0.0268 & 0.7305 & na & 0.4305 & 0.9431 \\
\hline \multicolumn{8}{|l|}{$\begin{array}{l}\text { First ratoon } \\
\quad(2016-2017)\end{array}$} \\
\hline СР96-1252 & 100 & $15.37 \mathrm{a}$ & $21.39 \mathrm{a}$ & $3.29 \mathrm{a}$ & $369 \mathrm{a}$ & na & na \\
\hline СР96-1252 & 7 & $15.72 \mathrm{a}$ & $21.34 \mathrm{a}$ & $3.33 \mathrm{ab}$ & $365 \mathrm{a}$ & na & na \\
\hline CL88-4730 & 100 & $17.32 \mathrm{~b}$ & $21.83 \mathrm{ab}$ & $3.78 \mathrm{ab}$ & $284 \mathrm{~b}$ & na & na \\
\hline CL88-4730 & 7 & $17.81 \mathrm{~b}$ & $22.50 \mathrm{~b}$ & $4.01 \mathrm{~b}$ & $284 \mathrm{~b}$ & na & na \\
\hline $\begin{array}{l}\text { Linear mixed } \\
\text { effect }\end{array}$ & & $F<P$ & & & & & \\
\hline Cultivar effect & & 0.0386 & 0.0080 & 0.0037 & $<0.0001$ & na & na \\
\hline Infection effect & & 0.6447 & 0.2573 & 0.4332 & 0.8822 & na & na \\
\hline $\begin{array}{l}\text { Cultivar } \times \\
\text { infection effect }\end{array}$ & & 0.9362 & 0.1870 & 0.5927 & 0.8912 & na & na \\
\hline \multicolumn{8}{|l|}{$\begin{array}{l}\text { Second ratoon } \\
(2017-2018)\end{array}$} \\
\hline СР96-1252 & 100 & $14.65 \mathrm{a}$ & $20.14 \mathrm{a}$ & $2.95 \mathrm{a}$ & $418 \mathrm{a}$ & $50.66 \mathrm{a}$ & $10.20 \mathrm{a}$ \\
\hline СР96-1252 & 2 & $14.15 \mathrm{a}$ & $20.10 \mathrm{a}$ & $2.84 \mathrm{a}$ & $407 \mathrm{a}$ & $69.31 \mathrm{~b}$ & $13.93 \mathrm{~b}$ \\
\hline CL88-4730 & 100 & $14.24 \mathrm{a}$ & $20.56 \mathrm{ab}$ & $2.92 \mathrm{a}$ & $267 \mathrm{~b}$ & $46.18 \mathrm{a}$ & $9.46 \mathrm{a}$ \\
\hline CL88-4730 & 7 & $14.41 \mathrm{a}$ & $21.15 \mathrm{~b}$ & $3.04 \mathrm{a}$ & $267 \mathrm{~b}$ & $47.64 \mathrm{a}$ & $10.06 \mathrm{a}$ \\
\hline $\begin{array}{l}\text { Linear mixed } \\
\text { effect }\end{array}$ & & $F<P$ & & & & & \\
\hline Cultivar effect & & 0.9333 & 0.0002 & 0.6393 & $<0.0001$ & 0.0004 & 0.0010 \\
\hline Infection effect & & 0.8526 & 0.0947 & 0.9736 & 0.6464 & 0.0031 & 0.0017 \\
\hline $\begin{array}{l}\text { Cultivar } \times \\
\text { infection effect }\end{array}$ & & 0.7107 & 0.0584 & 0.5148 & 0.6655 & 0.0087 & 0.0144 \\
\hline
\end{tabular}

\footnotetext{
${ }^{x}$ Highest prevalence of SCYLV during the crop cycle.

${ }^{y}$ In the column and for each crop cycle, the data followed by the same letter are nonsignificantly different at $P=0.05$ according to Tukey's test; na, not available.

${ }^{\mathrm{z}}$ Tonnage calculated based on two-row weight data.
} 
(Espinoza Delgado et al. 2016). Differences in aphid populations in weeds surrounding our experimental fields may, therefore, have also impacted infection level of healthy sugarcane, although M. sacchari aphids from sugarcane and sorghum are considered to be different biotypes and belong to different genotypes (Nibouche et al. 2015, 2018). The capacity of these biotypes to spread SCYLV to the alternative host has yet to be studied.

A decrease in prevalence of SCYLV from one sampling date to another was sometimes observed in initially $100 \%$ infected cultivars or healthy plots that had become infected by the virus. This was particularly noticeable in first ratoon crop of CP96-1252 when SCYLV was no longer detected in later months at Townsite. This apparent disappearance of the virus could be attributed to virus titer variations during sugarcane growth and occurrence of virus concentrations that are below detection level by TBIA. Luteoviruses, such as barley yellow dwarf virus (BYDV), can occur in low concentrations within the plant, which subsequently negatively affects virus transmission by aphids and undermines their detection by serological methods, like TBIA (Gray et al. 1991; Jiménez-Martínez and Bosque-Pérez 2004; Lin et al. 1990; Naidu and Hughes 2003). Furthermore, detecting BYDV by TBIA in one plant tiller does not guarantee detection in all tillers of the same plant (Makkouk and Comeau 1994). Because sugarcane produces abundant tillers, it is also possible that the number of leaves collected per plot at each sampling during the course of the study was insufficient to compensate for infection variability within each sugarcane plot or stool.

Significant yield losses owing to yellow leaf have been previously reported in several geographical locations, including Florida. Yield differences between healthy and infected plants are usually observed in all crop cycles (Comstock and Miller 2004; Grisham et al. 2002, 2009; Lehrer et al. 2009; Rassaby et al. 2003; Vega et al. 1997; Viswanathan et al. 2014; Zhu et al. 2010). In this study, despite high differences in SCYLV infection levels between healthy and infected sugarcane plots, no negative effect owing to the virus was found in plant cane crop, regardless of cultivar and location. This could be related to low-disease buildup in plant cane, although stalk cuttings used as seed cane were already infected and originated from diseased plants. The three varieties planted at Ritta or Townsite could also be considered as tolerant to yellow leaf in plant cane (i.e., infected by the virus without impact of virus infection on yield) (Agrios 2005; Roossinck 2012; Schafer 1971). This result might be related to the breeding process in Florida, where varieties are not eliminated because of infection by SCYLV but rather, are screened and selected based on tonnage and sucrose content. Over decades of breeding and screening with the presence of SCYLV, the best-yielding varieties may no longer be affected by yellow leaf in plant cane. The breeding process may also have unintentionally selected clones with modulated carbohydrate metabolism to avoid or compensate for the adverse effects of SCYLV infection (Lehrer et al. 2010).

An overall positive effect on sucrose concentration was, however, observed in SCYLV-infected stalks versus noninfected ones at Ritta in plant cane. SCYLV infection can result in alterations in photosynthetic efficiency and carbohydrate accumulation in sugarcane leaves (Gonçalves et al. 2005). Consequently, carbohydrate levels in infected leaves can be higher than in virus-free leaves. Sugar concentration per gram of internodes was also reported slightly higher in virus-infected plants than in virus-free plants (Lehrer et al. 2007). However, higher sucrose concentration in virus-infected stalks could also be attributed to presence of another stalk pathogen, such as Leifsonia xyli subsp. xyli, the causal agent of ratoon stunting (Davis and Bailey 2000). Plants infected by this bacterium do not exhibit reliable or characteristic external symptoms. L. xyli subsp. xyli colonizes the xylem and can, therefore, be responsible for alteration in stalk physiology and sometimes, increased sugar content (Kao and Damann 1978; Koike 1974; Rossler 1974). However, only very few stalks were found infected by this pathogen in our experimental fields (data not shown), and there was no significant difference between virus-infected and virus-free plants. This suggested that ratoon stunting was not responsible for higher sucrose concentrations in infected plants in our study.
Although SCYLV had no detectable negative effect on plant growth or sucrose content in plant cane, the virus caused yield losses expressed as tons of sugar per hectare in CL77-0797 in first (14\%) and second (19\%) ratoon crop at Ritta and CP96-1252 in second ratoon crop (27\%) at Townsite. Yield losses might also have occurred in first ratoon crop of CP96-1252 at Townsite, but harvest data using the two-row method could not be determined because of technical issues with the hydraulic scale. CP96-1252 was not significantly affected by SCYLV at Ritta regardless of crop cycle but suffered high yield losses at Townsite. This suggested that growing conditions, such as soil or fertilization, also play a role in the impact of yellow leaf on sugarcane growth and sucrose accumulation. As an example, symptoms of sugarcane brown rust (caused by Puccinia melanocephala) are more severe when plants are grown in soils with high fertility levels (Anderson et al. 1990; Johnson et al. 2007).

Two different sampling procedures were used herein to determine sugarcane stalk weight: the 10-stalk method and the two-row method. The latter one requires more sophisticated harvesting/ weighing material but proved to be more efficient in determining yield losses compared with the 10-stalk method, which is usually used to determine yield data in experimental fields in Florida.

Plants that tested positive for SCYLV at Townsite were exclusively infected by genotype BRA, whereas virus-infected plants at Ritta were infected by both genotypes BRA and CUB. However, genotype BRA was also predominant at Ritta, because it was found in $92 \%$ of samples, and genotype CUB was in only $30 \%$ of samples. Both genotypes were apparently spread in our experimental field at Ritta, because they were detected in plants that were issued from virus-free cuttings at planting. The biological significance of these genotypes is unknown, but genotype CUB was found more virulent than genotype BRA in controlled inoculation studies (Abu Ahmad et al. 2007). Furthermore, genotype CUB was hypothesized to have been introduced more recently into Florida than genotype BRA (Filloux et al. 2018). Occurrence of genotype CUB in CP96-1252 at Ritta, but not at Townsite, suggests that this genotype was introduced into the research plots from cane surrounding the Ritta location. If genotype CUB continues to spread in Florida in the future, impact of SCYLV on sugarcane production may also change. Furthermore, presence of mixed virus infection with genotypes BRA and CUB may also favor viral recombination and development of new variants of the virus (Lin et al. 2014).

High prevalence ( 70 to $100 \%$ ) of SCYLV in sugarcane commercial fields in Florida (C. Kaye, unpublished data) (Filloux et al. 2018) suggested rapid infection of healthy plants. However, this was not observed in this study, where a maximum of 7 to $33 \%$ of plants became infected over a 3.5-year period. Therefore, high prevalence of SCYLV in Florida seems to be owing to propagation and planting of virus-infected material rather than insect spread of the virus. Consequently, rigorous screening of sugarcane nurseries, planting of virus-free seed cane, and good site management practices (control of the weed S. almum) should limit the impact of yellow leaf on sugarcane production in Florida.

\section{Acknowledgments}

We thank Lee Davis, Ezequiel Esparza, Young-Jin Kim, Victor Williams, and Alphonso Lyman for their help to plant and weigh sugarcane and analyze stalk sugar content.

\section{Literature Cited}

Abu Ahmad, Y., Costet, L., Daugrois, J.-H., Nibouche, S., Letourmy, P., Girard, J.-C., and Rott, P. 2007. Variation in infection capacity and in virulence exists between genotypes of Sugarcane yellow leaf virus. Plant Dis. 91:253-259.

Abu Ahmad, Y., Rassaby, L., Royer, M., Borg, Z., Braithwaite, K. S., Mirkov, T. E., Irey, M. S., Perrier, X., Smith, G. R., and Rott, P. 2006a. Yellow leaf is caused by at least three different genotypes of sugarcane yellow leaf virus, one of which predominates on the Island of Réunion. Arch. Virol. 151: 1355-1371.

Abu Ahmad, Y., Royer, M., Daugrois, J.-H., Costet, L., Lett, J. M., Victoria, J. I., Girard, J.-C., and Rott, P. 2006b. Geographical distribution of four Sugarcane yellow leaf virus genotypes. Plant Dis. 90:1156-1160. 
Agrios, G. N. 2005. Introduction to Plant Pathology. Elsevier Academic Press, Amsterdam, The Netherlands.

Anderson, D. L., Raid, R. N., Irey, M. S., and Henderson, L. J. 1990. Association of sugarcane rust severity with soil factors in Florida. Plant Dis. 74:683-686.

Chinnaraja, C., Viswanathan, R., Karuppaiah, R., Bagyalakshmi, K., Malathi, P., and Parameswari, B. 2013. Complete genome characterization of Sugarcane yellow leaf virus from India: Evidence for RNA recombination. Eur. J. Plant Pathol. 135:335-349.

Comstock, J. C., Irey, M. S., Lockhart, B. E. L., and Wang, Z. K. 1998. Incidence of yellow leaf syndrome in CP cultivars based on polymerase chain reaction and serological techniques. Sugar Cane 4:21-24.

Comstock, J. C., and Miller, J. D. 2004. Yield comparisons: Disease-free tissue culture versus bud-propagated sugarcane plants and healthy versus yellow leaf infected plants. J. Am. Soc. Sugar Cane Technol. 24:31-40.

Comstock, J. C., Miller, J. D., and Schnell, R. J. 2001. Incidence of Sugarcane yellow leaf virus in clones maintained in the world collection of sugarcane and related grasses at the United States National Repository in Miami, Florida. Sugar Tech 3:128-133.

Daugrois, J.-H., Edon-Jock, C., Bonoto, S., Vaillant, J., and Rott, P. 2011. Spread of Sugarcane yellow leaf virus in initially disease-free sugarcane is linked to rainfall and host resistance in the humid tropical environment of Guadeloupe. Eur. J. Plant Pathol. 129:71-80.

Davis, M. J., and Bailey, R. A. 2000. Ratoon stunting. Pages 49-54 in: A Guide to Sugarcane Diseases. P. Rott, R. A. Bailey, J. C. Comstock, B. J. Croft, and A. S. Saumtally, eds. La Librairie du Cirad, Montpellier, France.

Edon-Jock, C., Daugrois, J.-H., Jacquet, O., and Vaillant, J. 2009. Analysis of spatio-temporal spread of Sugarcane yellow leaf virus in a disease free plot using point process. Pages 35-37 in: Proceedings of the 10th International Epidemiology Workshop, New York.

Espinoza Delgado, H. V., Kaye, C., Hincapie, M., Boukari, W., Wei, C., Fernandez, J. V., Mollov, D., Comstock, J. C., and Rott, P. 2016. First report of Sugarcane yellow leaf virus infecting Columbus grass (Sorghum almum) in Florida. Plant Dis. 100:1027-1028.

Filloux, D., Fernandez, E., Comstock, J. C., Mollov, D., Roumagnac, P., and Rott, P. 2018. Viral metagenomic-based screening of sugarcane from Florida reveals occurrence of six sugarcane-infecting viruses and high prevalence of Sugarcane yellow leaf virus. Plant Dis. 102:2317-2323.

Girard, J.-C., Fernandez, E., Daugrois, J.-H., Roques, D., Roumagnac, P., and Rott, P. 2010. Genetic diversity of Sugarcane yellow leaf virus in a sugarcane selection plot in Guadeloupe (FWI). Proc. Intern. Soc. Sugar Cane Technol. 27:1123-1129.

Gonçalves, M. C., Vega, J., Oliveira, J. G., and Gomes, M. 2005. Sugarcane yellow leaf virus infection leads to alterations in photosynthetic efficiency and carbohydrate accumulation in sugarcane leaves. Fitopatol. Bras. 30:10-16.

Gray, S. M., Power, A. G., Smith, D. M., Seaman, A. J., and Altman, N. S. 1991. Aphid transmission of barley yellow dwarf virus: Acquisition access periods and virus concentration requirements. Phytopathology 81:539-545.

Grisham, M. P., Eggleston, G., Hoy, J. W., and Viator, R. P. 2009. The effect of Sugarcane yellow leaf virus infection on yield of sugarcane in Louisiana. Sugar Cane Intern. 27:91-94.

Grisham, M. P., Pan, Y. B., White, W. H., Godshall, M. A., Legendre, B. L., and Comstock, J. C. 2002. Potential effect of yellow leaf syndrome on the Louisiana sugarcane industry. J. Am. Soc. Sugar Cane Technol. 22:125-126.

Hall, D. G. 1987. The sugarcane aphid, Melanaphis sacchari (Zehntner), in Florida. J. Am. Soc. Sugar Cane Technol. 7:26-29.

Hothorn, T., Bretz, F., Westfall, P., Heiber, R. M., Schuetzenmeister, A., and Scheibe, S. 2017. Multcomp: Simulataneous Inference in General Parametric Models. R Package Version 1.4.8. http://multcomp.r-forge.r-project.org/

Jiménez-Martínez, E. S., and Bosque-Pérez, N. A. 2004. Variation in barley yellow dwarf virus transmission efficiency by Rhopalosiphum padi (Homoptera: Aphididae) after acquisition from transgenic and nontransformed wheat genotypes. J. Econ. Entomol. 97:1790-1796.

Johnson, R. M., Grisham, M. P., and Richard, E. P. 2007. Relationship between sugarcane rust severity and soil properties in Louisiana. Phytopathology 97: $748-755$

Kao, J., and Damann, K. E., Jr. 1978. Microcolonies of the bacterium associated with ratoon stunting disease found in sugarcane xylem matrix. Phytopathology 68:545-551.

Kennedy, J. S., Booth, C. O., and Kershaw, W. J. S. 1959. Host finding by aphids in the field. II. Aphis fabae Scop. (Gynoparae) and Brevicoryne brassicae L.; with a reappraisal of the role of host finding behaviour in virus spread. Ann. Appl. Biol. 47:424-444.

Kennedy, J. S., Booth, C. O., and Kershaw, W. J. S. 1961. Host finding by aphids in the field. III. Visual attraction. Ann. Appl. Biol. 49:1-21.

Koike, H. 1974. Interaction between diseases on sugarcane: Sugarcane mosaic and ratoon stunting disease. Proc. Intern. Soc. Sugar Cane Technol. 15:258-265.

Komor, E., El-Sayed, A., and Lehrer, A. T. 2010. Sugarcane yellow leaf virus introduction and spread in Hawaiian sugarcane industry: Retrospective epidemiological study of an unnoticed, mostly asymptomatic plant disease. Eur. J. Plant Pathol. 127:207-217.
Kring, J. B. 1972. Flight behaviour of aphids. Annu. Rev. Entomol. 17:461-492.

Lehrer, A., Yan, S. L., Fontaniella, B., El-Sayed, A., and Komor, E. 2010. Carbohydrate composition of sugarcane cultivars that are resistant or susceptible to Sugarcane yellow leaf virus. J. Gen. Plant Pathol. 76:62-68.

Lehrer, A. T., Moore, P. H., and Komor, E. 2007. Impact of Sugarcane yellow leaf virus (ScYLV) on the carbohydrate status of sugarcane: Comparison of virusfree plants with symptomatic and asymptomatic virus-infected plants. Physiol. Mol. Plant Pathol. 70:180-188.

Lehrer, A. T., Schenck, S., Wu, K. K., and Komor, E. 2009. Impact of Sugarcane yellow leaf virus on growth and sugar yield of sugarcane. J. Gen. Plant Pathol. 75:288-296.

Lenth, R. V., Love, J., and Herve, M. 2018. Emmeans: Estimated Marginal Means, aka Least-Squares Means. R Package Version 1.1.3. https://github.com/rvlenth/ emmeans

Lin, N. S., Hsu, Y. H., and Hsu, H. T. 1990. Immunological detection of plant viruses and a mycoplasma-like organism by direct tissue blotting on nitrocellulose membranes. Phytopathology 80:824-828.

Lin, Y.-H., Gao, S.-J., Damaj, M. B., Fu, H.-Y., Chen, R.-K., and Mirkov, T. E. 2014. Genome characterization of Sugarcane yellow leaf virus from China reveals a novel recombinant genotype. Arch. Virol. 159:1421-1429.

Makkouk, K. M., and Comeau, A. 1994. Evaluation of various methods for the detection of barley yellow dwarf virus by the tissue-blot immunoassay and its use for virus detection in cereals inoculated at different growth stages. Eur. J. Plant Pathol. 100:71-80.

McAllister, C. D., Hoy, J. W., and Reagan, T. E. 2008. Temporal increase and spatial distribution of sugarcane yellow leaf and infestations of the aphid vector Melanaphis sacchari. Plant Dis. 92:607-615.

Naidu, R. A., and Hughes, J. D. A. 2003. Methods for the detection of plant virus diseases. Pages 233-253 in: Proceedings of a Conference on Plant Virology in Sub Saharan Africa organized by the IITA, 4-8 June 2001, Ibadan, Nigeria.

Nibouche, S., Costet, L., Holt, J. R., Jacobson, A., Pekarcik, A., Sadeyen, J., Armstrong, J. S., Peterson, G. C., McLaren, N., and Medina, R. F. 2018. Invasion of sorghum in the Americas by a new sugarcane aphid (Melanaphis sacchari) superclone. PLoS One 13:e0196124.

Nibouche, S., Mississipi, S., Fartek, B., Delatte, H., Reynaud, B., and Costet, L. 2015. Host plant specialization in the sugarcane aphid Melanaphis sacchari. PLoS One 10:e0143704.

Rassaby, L., Girard, J.-C., Lemaire, O., Costet, L., Irey, M. S., Kodja, H., Lockhart, B. E. L., and Rott, P. 2004. Spread of Sugarcane yellow leaf virus in sugarcane plants and fields on the island of Reunion. Plant Pathol. 53:117-125.

Rassaby, L., Girard, J.-C., Letourmy, P., Chaume, J., Irey, M. S., Lockhart, B. E. L., Kodja, H., and Rott, P. 2003. Impact of Sugarcane yellow leaf virus on sugarcane yield and juice quality in Reunion Island. Eur. J. Plant Pathol. 109: 459-466.

Roossinck, M. J. 2012. Plant virus metagenomics: Biodiversity and ecology. Annu. Rev. Genet. 46:359-369.

Rossler, L. A. 1974. The effects of ratoon stunting disease on three sugarcane varieties under different irrigation regimes. Proc. Intern. Soc. Sugar Cane Technol. 15:250-257.

Rott, P., Mirkov, T. E., Schenck, S., and Girard, J. C. 2008. Recent advances in research on Sugarcane yellow leaf virus, the causal agent of sugarcane yellow leaf. Sugar Cane Intern. 26:18-27.

Rott, P. C., Kaye, C., Naranjo, M., Shine, J. M., Jr., Sood, S., Comstock, J. C., and Raid, R. N. 2016. Controlling sugarcane diseases in Florida: A challenge in constant evolution. Proc. Intern. Soc. Sugar Cane Technol. 29:595-600.

Schafer, J. F. 1971. Tolerance to plant disease. Annu. Rev. Phytopathol. 9: 235-252.

Schenck, S., Hu, J. S., and Lockhart, B. E. L. 1997. Use of a tissue blot immunoassay to determine the distribution of Sugarcane yellow leaf virus in Hawaii. Sugar Cane 4:5-8.

Schenck, S., and Lehrer, A. T. 2000. Factors affecting the transmission and spread of Sugarcane yellow leaf virus. Plant Dis. 84:1085-1088.

USDA-NRCS. 1991. U.S. Department of Agriculture-Natural Resources Conservation. Soil Survey of Hendry County, Florida. https://www.nrcs.usda gov/Internet/FSE_MANUSCRIPTS/florida/FL051/0/Hendry.pdf

Vega, J., Scagliusi, S. M. M., and Ulian, E. C. 1997. Sugarcane yellow leaf disease in Brazil: Evidence of association with a luteovirus. Plant Dis. 81:21-26.

Viswanathan, R., Chinnaraja, C., Malathi, P., Gomathi, R., Rakkiyappan, P., Neelamathi, D., and Ravichandran, V. 2014. Impact of Sugarcane yellow leaf virus (ScYLV) infection on physiological efficiency and growth parameters of sugarcane under tropical climatic conditions in India. Acta Physiol. Plant. 36:1805-1822

Wang, M.-Q., Xu, D. L., Li, R., and Zhou, G. H. 2012. Genotype identification and genetic diversity of Sugarcane yellow leaf virus in China. Plant Pathol. 61: 986-993.

Zhu, Y. J., Lim, S. T. S., Schenck, S., Arcinas, A., and Komor, E. 2010. RT-PCR and quantitative real-time RT-PCR detection of Sugarcane yellow leaf virus (SCYLV) in symptomatic and asymptomatic plants of Hawaiian sugarcane cultivars and the correlation of SCYLV titer to yield. Eur. J. Plant Pathol. $127: 263-273$ 